Australian Journal of

Crop Science

AJCS

AJCS 13(06):1009-1016 (2019)

ISSN:1835-2707

doi: 10.21475/ajcs.19.13.06.p1965

\title{
Adaptation and stability of cowpea (Vigna unguiculata (L.) Walp) bean cultivars in the tropical dry forest of Colombia
}

\author{
Hermes Araméndiz-Tatis ${ }^{1 *}$, Miguel Espitia-Camacho ${ }^{2}$, Carlos Cardona-Ayala ${ }^{3}$ \\ ${ }^{1}$ Universidad de Córdoba, Carrera 6 No. 76-103, Montería, Colombia, Grupo de Investigación Cultivos Tropicales de \\ Clima Cálido [Research Group on Tropical Crops of Warm Climates], Colombia
}

\author{
*Corresponding author: haramendiz@correo.unicordoba.edu.co
}

\begin{abstract}
Cowpea (Vigna unguiculata (L.) Walp) is a source of low cost protein for food, and is currently used in family farming in northern Colombia. The aim of this study was to estimate the adaptability and phenotypic stability of the grain yield (per hectare) of nine advanced lines (plus control) of cowpea and a commercial control in eight contrasting environments of the tropical dry forest of the Colombian Caribbean region. We employed five analysis methods: Eberhart and Russell, Lin and Binns, Annichiarico, Carneiro, and Nascimento et al. A completely randomized block design was used with 9 genotypes +1 control and four repetitions per environment. The analysis of variance detected significant differences in environments, genotypes and in the genotype $x$ environment interaction, confirming that the crops have become sensitive to differences of the environments. At the same time, we forced to consider adaptability and stability for the selection of the best genotype. The five methods of analysis coincided with identification of line L-019 as the best genotype due to its grain yield, adaptability and phenotypic stability. Therefore, L-019 is a new planting alternative for family agriculture of cowpea producers in the Colombian Caribbean.
\end{abstract}

Keywords: Cowpea, cultivar assessments, genotype by environment interaction, grain yield, stability parameters.

Abbreviations: d.f_degree of freedom; lid_ confidence index for unfavourable environments; lif_confidence index for favourable

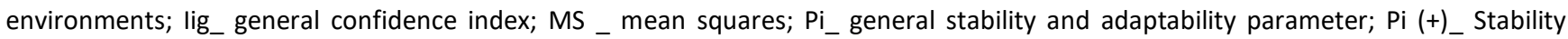
parameter for favourable environments; $\mathrm{Pi}(-)_{-}$Stability parameter for unfavourable environments; SS _ Sum of squares (\%); S2di _ regression deviation; I: General adaptability; II: Maximum specific adaptability to favourable environments ; III: Maximum specific adaptability to unfavourable environments; IV: Minimum adaptability; V: Average general adaptability /VI: Medium specific adaptability to favourable environments; VII: Average specific adaptability to unfavourable environments; $\beta 1$ regression coefficient.

\section{Introduction}

Cowpea is the most important legume cultivated in the Colombian Caribbean, with an approximate area of 14,000 ha. This activity is carried out under family farming production systems with variable agronomic management conditions of soil and climate, which have an impact on the differential behaviour of the cultivated varieties. For this reason, in the final phase of a genetic breeding program, it is of great importance to know the behaviour of the advanced lines in contrasting environmental conditions and in producer plots. This is due to identification of the genotypes with better grain yields, adaptability, stability and complementary desirable agronomic characteristics, such as drought tolerance, plant architecture, grain and nutritional characteristics, which are favourable for production conditions in which they will be sown (Melo et al., 2018).

The average grain yield of the varieties grown by producers is $600 \mathrm{~kg} \mathrm{ha}^{-1}$, that compared to the 1,835 and $1,379 \mathrm{~kg} \mathrm{ha}^{-1}$ obtained in the United States and Peru, respectively (FAOSTAT, 2018), are low due to abiotic and biotic factors that affect on yield. Among these, the low genetic potential of production can be highlighted. This, in turn, can be associated with the genotype $x$ environment interaction (GXE), making the sustainability of the crop much more critical, forcing country to import this legume to meet domestic needs.

There are limitations that GxE interaction poses to a genetic breeding program such as changes in the classification or range of genotypes among the environments, phenotypic plasticity of the feature of interest, and decrease in the correlation between phenotypic and genotypic values. These limitations reduce the selection progress and cause difficulty in the selection and subsequent recommendation of genotypes for one or several localities (Abate et al., 2015). In this way, their analysis and interpretation are necessary to define a strategy, either by selecting genotypes with broad or specific adaptation or by identifying mega-environments (Farshadfar et al., 2012). 
Nevertheless, numerous methods have been used over time for selection of genotypes in different cultivated species. They are increasingly precise and refined by yield, adaptability and stability, as well as parametric. Furthermore, nonparametric statistical models have been proposed as well. Among these methods, we chose Liu et al. (2011), Farshadfar et al. (2012), Karimizadeh et al. (2012), Sahin et al. (2012), Sabaghnia et al. (2013), Gedif et al. (2014), Vange et al. (2014), Abate et al. (2015), and Inácio et al. (2018).

Adaptability and stability methods differ in their biometric principles to measure GXE interaction. One of these is the one proposed by Eberhart and Russell (1966), which is based on a regression analysis and measures the response of each genotype to environmental variations, standing out for its use. Annichiarico (1992) proposed a method based on the analysis of variance. Moreover, nonparametric analyses are the ones published by Lin and Binns (1988) and Carneiro (1998) using parametric indices as Pi, Pif, and Pid. Further, Nascimento et al. (2009) proposed centroid analysis, which compares the Cartesian distance between the genotypes and seven reference ideotypes based on their general and specific adaptability in favourable and unfavourable environments, as well as those of minimum adaptability.

Hühn (1990) argued that parametric stability methods demand compliance with the normal distribution of errors and interaction effects. They may not work well if these assumptions are violated. Therefore, the author states that the nonparametric methods have the following advantages: reduction of the bias caused by outliers, these do not demand assumptions about value distribution, they are easy to apply and interpret, and allow the addition or elimination of one or few genotypes without causing variation in the results.

The genetic breeding associated with the participation of producer communities is vital in the selection process and adoption of new genotypes that respond to their conditions, requirements and needs. For this reason, the evaluation of these genotypes in contrasting environments allows the selection of higher adaptability genotypes. It is well-known that some genotypes have better ability to respond positively to environmental stimuli and stability, such as the predictable behaviour of genotypes based on environmental supply (Cruz et al., 2004). The success of a breeding program lies in its ability to identify and recommend cultivars to producers that guarantee excellent yields and/or quality of its products in a wide range of environments (Malosetti et al., 2013).

According to the aforementioned, the aim of this study was to estimate the adaptability and phenotypic stability of the grain yield of nine advanced lines and a commercial control of $V$. unguiculata, in eight contrasting environments of the tropical dry forest of the Colombian Caribbean region employing five analysis methods. Among these we include Eberhart and Russell (1966), Lin and Binns (1988), Annichiarico (1992), Carneiro (1998) and Nascimento et al. (2009). This study mainly aims to select the genotypes with the highest potential for family farming.

\section{Results and discussion}

\section{Combined analysis of variance for grain yield}

The results of the analysis of combined variance for grain yield are reported in Table 1 . The effects of the environment, genotype and genotype by environment interaction (GxE), showed highly significant differences $(P \leq 0.01)$. This indicates that at least two environments or two genotypes were statistically different in grain yield, and likewise, the genotypes showed sensitivity to environmental effects. This generates changes in the classification or range of genotypes between environments, masking the expression of the character of interest, decreasing the correlation between phenotypic and genotypic values, reducing the selection progress, and finally, hinders the selection work and subsequent recommendation of the genotypes for one or several locations (Abate et al., 2015).

\section{Contribution of the source of variation in percentage}

The contribution of each of the sources to the total variability of the sums of squares (SS) of the model was $71.78 \%$ (Environment), $12.02 \%$ (Genotypes) and $16.20 \%$ (GXE), which indicates a great discrepancy between the environments, causing differences between the environmental means in grain yield of the genotypes and in the GxE interaction (Table 1). These results are in agreement with Cholin et al. (2010), Nunes et al. (2014), Silva et al. (2016), Sousa et al. (2017) and Melo et al. (2018). The presence of the GxE interaction makes it necessary to consider the adaptability and phenotypic stability of the evaluated genotypes. This is to carry out a rigorous and precise selection process when a new cultivar is being released commercially with general or specific adaptations to producing areas in the Colombian Caribbean (Nunes et al., 2014; Silva et al., 2016; Sousa et al., 2017; Melo et al. (2018).

The coefficient of variation that measures the experimental precision (Table 1 ) is considered of medium precision, for accusing a value between $10 \%$ and $20 \%$, and agrees with values reported by Nunes et al. (2014), Silva et al. (2016), Sousa et al. (2017) and Melo et al. (2018).

\section{Adaptability and stability methods}

Results of the GxE interaction were highly significant for grain yield due to the differential response of the genotypes to the effects of the environments. It is important to identify cultivars with wide adaptability or those less affected by the environment (Vilela et al., 2011; Vange et al., 2014; Abate et al., 2015). This must be carried out relying on different phenotypic stability methods and to decide based on the coherence of the results of the methods applied. 
Table 1. Mean squares of the combined analysis of variance for yield in eight environments of tropical dry forest of the Caribbean region 2017B - 2018A.

\begin{tabular}{lccc}
\hline Variation sources & d.f. & MS yield & SS (\%) \\
\hline Environment (E) & 7 & $8563295.50^{* *}$ & 71.78 \\
Genotype (G) & 9 & $1115131.34^{* *}$ & 12.02 \\
Interaction GxE & 63 & $214723.14^{* *}$ & 16.20 \\
Combined error & 216 & 47988.19 & \\
Total & 319 & 301.925 & \\
Mean & & 1134.75 & \\
C.V. $(\%)$ & & 19.30 & \\
\hline
\end{tabular}

d.f.: degrees of freedom; MS: mean squares.

Table 2. Stability indices of different methodologies for yield $\left(\mathrm{kg} \mathrm{ha}^{-1}\right)$ in 10 cowpea cultivars in eight environments of tropical dry forest of the Colombian Caribbean 2017B-2018A.

\begin{tabular}{|c|c|c|c|c|c|c|c|c|c|c|c|}
\hline \multirow[t]{2}{*}{ Genotype } & \multirow[t]{2}{*}{ Mean } & \multirow{2}{*}{$\begin{array}{c}\text { Lin and Binns } \\
\text { Pi }\end{array}$} & \multicolumn{2}{|c|}{ Carneiro } & \multicolumn{2}{|c|}{ Eberhart and Russell } & \multicolumn{2}{|c|}{ Centroid } & \multicolumn{2}{|c|}{ Annichiarico } & \multirow[b]{2}{*}{$\begin{array}{l}\text { Fav. } \\
\text { (lif) }\end{array}$} \\
\hline & & & $\mathrm{Pi}(+)$ & $\mathrm{Pi}(-)$ & $\beta i$ & $S^{2} \mathrm{di}$ & Class & $\begin{array}{c}\text { Probability } \\
(\%)\end{array}$ & $\begin{array}{c}\text { General } \\
\text { (lig) }\end{array}$ & $\begin{array}{l}\text { Unfav. } \\
\text { (lid) }\end{array}$ & \\
\hline LC-029-016 & 944.3 b (1) & $305680.50(9)$ & $304791(6)$ & $306213(10)$ & 1.04 & 16023.91* & IV & 26.35 & 81.07 & 77.02 & 87.85 \\
\hline LC-002-016 & $1045.6 \mathrm{~b}$ & $214467.76(5)$ & $254252(5)$ & $190596(7)$ & 0.93 & 4639.97 & V & 38.62 & 91.97 & 90.88 & 93.80 \\
\hline LC-036-016 & $1050.0 \mathrm{ab}$ & $240987.13(6)$ & 376617 (8) & $159608(3)$ & 0.94 & 10465.37 & V & 33.09 & 92.42 & 94.34 & 89.23 \\
\hline LC-009-016 & $1031.3 \mathrm{~b}$ & $289108.98(8)$ & $468480(9)$ & $181486(5)$ & 0.92 & $40047.53^{* *}$ & $\mathrm{~V}$ & 26.54 & 91.34 & 93.74 & 87.83 \\
\hline LC-021-016 & $963.2 \mathrm{~b}$ & $342826.76(10)$ & $503488(10)$ & 246429 (9) & 0.92 & $47825.95 * *$ & IV & 29.74 & 84.28 & 86.09 & 81.26 \\
\hline L-019 & 1536.9 a & 10448.85 (1) & $18491(1)$ & $5623(1)$ & 0.91 & $187754.63^{* *}$ & I & 38.64 & 139.40 & 146.06 & 128.30 \\
\hline LC-006-016 & $1064.8 \mathrm{ab}$ & 55716.01 (7) & 365134 (7) & $90064(6)$ & 0.75 & $50587.07 * *$ & V & 25.57 & 96.13 & 94.44 & 97.15 \\
\hline LC-005-016 & $1159.6 \mathrm{ab}$ & 180747.53(4) & $164298(4)$ & $190616(8)$ & 1.22 & 3808.21 & $\mathrm{~V}$ & 37.71 & 99.66 & 95.33 & 106.88 \\
\hline LC-014-016 & $189.9 \mathrm{ab}$ & 44563.35 (3) & $90603(3)$ & 76939 (4) & 1.29 & 9633.03 & $\mathrm{~V}$ & 27.24 & 01.90 & 95.87 & 111.97 \\
\hline Caupicor 50 & $1362.1 \mathrm{ab}$ & $47977.94(2)$ & $36920(2)$ & $54612(2)$ & 1.05 & $33265.39 * *$ & $\mathrm{VI}$ & 17.62 & 121.76 & 123.48 & 118.91 \\
\hline
\end{tabular}

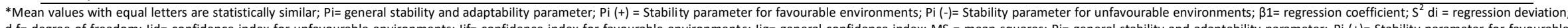

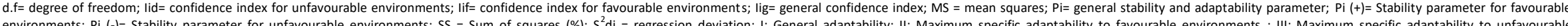

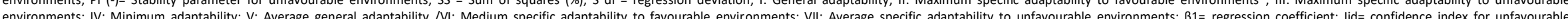
environments; lif = confidence index for favo : Arble environments: 


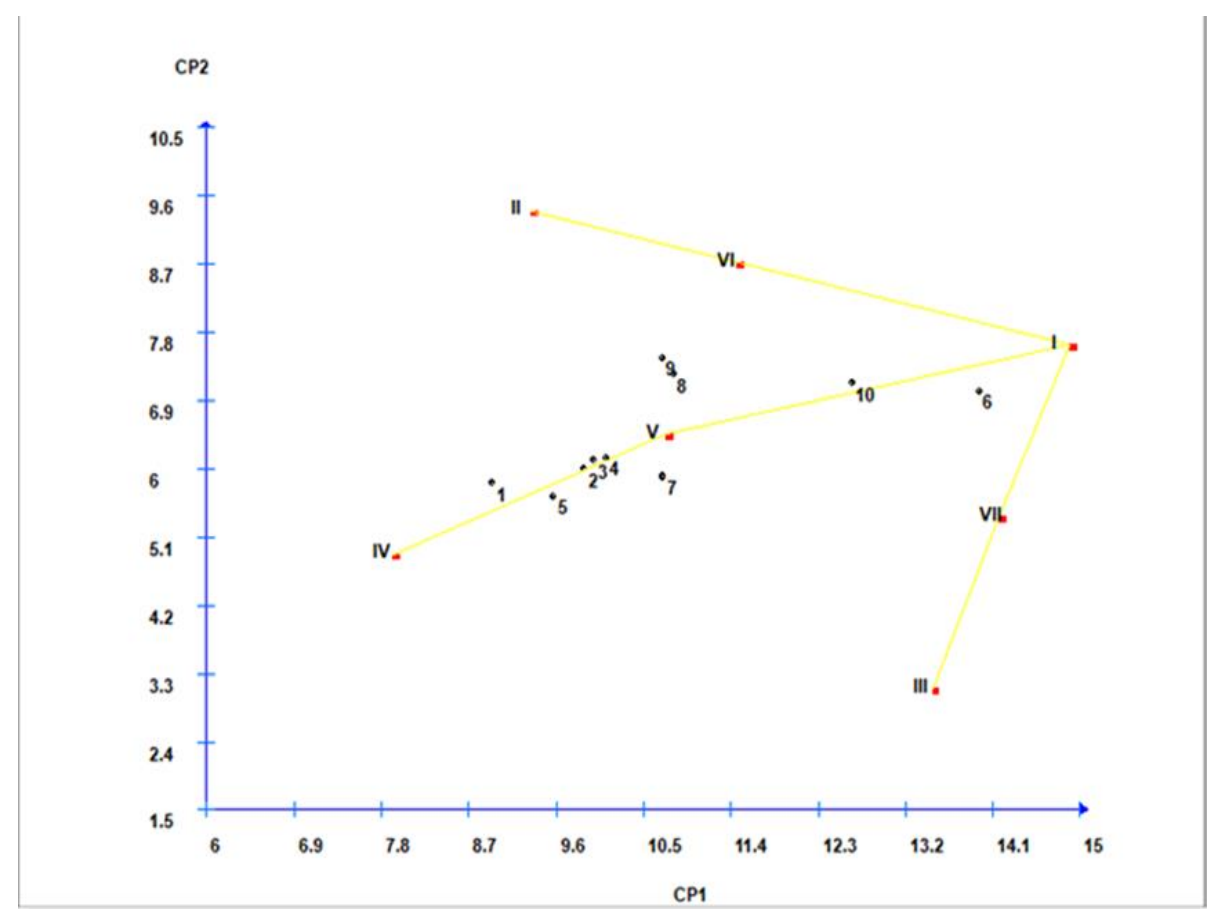

Fig 1. Adaptation of the genotypes according to their location in the centroids; the cardinals represent the genotypes and the roman numerals the centroid. 1= LC-029-016; $2=\mathrm{LC}-002-016 ; 3=\mathrm{LC}-036-016 ; 4=\mathrm{LC}-009-016 ; 5=\mathrm{LC}-021-016 ; 6=\mathrm{LC}-019 ; 7=\mathrm{LC}-006-016 ; 8=\mathrm{LC}-$ 005-016; 9= LC-014-016; 10= Caupicor 50 (control). I: General adaptability; II: Maximum specific adaptability to favourable environments; III: Maximum specific adaptability to unfavourable environments; IV: Minimum adaptability; V: Average general adaptability /VI: Medium specific adaptability to favourable environments; VII: Average specific adaptability to unfavourable environments. SS (\%): sum of squares (\%); C.V (\%): coefficient of variation (\%).

Table 3. Geographic coordinates of the places where the experiments were carried out.

\begin{tabular}{lllll}
\hline Map of Colombian Caribbean region & Locations & $\begin{array}{l}\text { Altitude } \\
(\mathrm{m})\end{array}$ & $\begin{array}{l}\text { South } \\
\text { Latitude }\end{array}$ & $\begin{array}{l}\text { West } \\
\text { longitude }\end{array}$ \\
\hline & Montería-Córdoba & 18 & $8^{\circ} 44^{\prime} 52^{\prime \prime}$ & $7^{\circ} 52^{\prime} 15^{\prime \prime}$ \\
& $\begin{array}{l}\text { Sampués-Sucre } \\
\text { Cartagena-Bolívar }\end{array}$ & 160 & $9^{\circ} 10^{\prime} 59^{\prime \prime}$ & $75^{\circ} 22^{\prime} 59^{\prime \prime}$ \\
& Mahates-Bolívar & 10 & $10^{\circ} 24^{\prime} 00^{\prime}$ & $75^{\circ} 30^{\prime} 00^{\prime \prime}$ \\
& Polonuevo-Atlántico & 66 & $10^{\circ} 13^{\prime} 59^{\prime \prime}$ & $75^{\circ} 10^{\prime} 59^{\prime \prime}$ \\
& Villanueva-Guajira & 235 & $10^{\circ} 40^{\prime} 01^{\prime \prime}$ & $74^{\circ} 51^{\prime} 00^{\prime \prime}$
\end{tabular}

Fuente: ArcGIS. 
Table 4. Name and origin of the ten genotypes of cowpea evaluated in eight environments of tropical dry forest of the Colombian Caribbean.

\begin{tabular}{lcc}
\hline Genotype & Cultivar & Origin \\
\hline LC-029-016 & Line & Colombia \\
LC-002-016 & Line & Colombia \\
LC-036-016 & Line & Colombia \\
LC-009-016 & Line & Colombia \\
LC-021-016 & Line & Colombia \\
LC-019 & Line & Colombia \\
LC-006-016 & Line & Colombia \\
LC-005-016 & Line & Colombia \\
LC-014-016 & Line & Colombia \\
Caupicor 50 & Commercial cultivar & Colombia \\
\hline
\end{tabular}

Table 5. Methods and indices of adaptability and phenotypic stability considered in this study.

\begin{tabular}{|c|c|}
\hline Stability indices and authors & Formulas \\
\hline $\begin{array}{l}\text { Stability parameters } \\
\text { Eberhart and Russell (1966) }\end{array}$ & $\begin{array}{l}\beta_{i}=\frac{\sum_{i=1}^{a} Y_{i j} Z_{i}}{\sum_{j=1}^{a} Z_{j}^{2}} \quad \text { where: } \beta_{i}=\text { regression coefficient } \\
S_{d i}^{2}=\frac{\left[\sum_{j=1}^{a}\left(Y_{i j}-\overline{Y_{l j}}\right)^{2}-\beta_{i}^{2} Z_{j}^{2}\right]}{(g-2)} \text { where: } S_{d i}^{2}=\text { regression deviation }\end{array}$ \\
\hline $\begin{array}{l}\text { Non-parametric statistics } \\
\text { Lin and Binns (1988) }\end{array}$ & $P_{i}=\frac{\sum_{j=1}^{a}\left(Y_{i j}-M_{j}\right)^{2}}{2 a}$ where: $M_{j}$ is the maximum performance obtained in environment $j$ \\
\hline $\begin{array}{l}\text { Non-parametric statistics } \\
\text { Carneiro (1998) }\end{array}$ & $\begin{array}{l}P_{i f}=\frac{\sum_{j=1}^{f}\left(X_{i f}-M_{f}\right)^{2}}{2 f} ; \quad P_{i d}=\frac{\sum_{d=1}^{d}\left(X_{i d}-M_{d}\right)^{2}}{2 d} \text { where } M_{f} \text { and } M_{d} \text {, are maximum yield in a } \\
\text { favourable and an unfavourable environment }\end{array}$ \\
\hline $\begin{array}{l}\text { Non-parametric statistics } \\
\text { Annichiarico (1992) }\end{array}$ & $I_{i}=\bar{Y}_{i,}-Z_{(1-\alpha)^{s i}}$ where: $I_{j}=$ confidence index \\
\hline $\begin{array}{l}\text { Non-parametric statistics } \\
\text { (Nascimento et al., 2009) }\end{array}$ & $\begin{array}{l}I_{j}=\frac{1}{g} \sum_{i} Y_{i j}-\frac{1}{a g} Y \ldots ; P_{d_{(i k)}}=\frac{\left(\frac{1}{d_{i k}}\right)}{\sum_{i \frac{1}{d i k}}} \text { where } I=\text { environmental index; } P_{d(i k)=} \text { is the } \\
\text { probability of having stability similar to the k-th centroid }\end{array}$ \\
\hline
\end{tabular}

\section{Eberhart and Russell (1966)}

Many investigations have used this methodology in cowpea (Cholin et al., 2010, Nunes et al., 2014, Silva et al., 2016). According to this method, the ideal cultivar is one that has high yield with a regression coefficient $\beta=1.0$ and $S^{2}$ di $=0$. In this sense, none of the cultivars showed this behaviour (Table 2). Nonetheless, genotypes LC-002-016, LC-036-016, LC-005-016 and LC-014-016 recorded values of $\beta=1.0$ and $S^{2} \mathrm{di}=0$, but lower yields than those recorded by the line L-019 and the cultivar Caupicor 50. These obtained values of $1,536.93 \mathrm{~kg} \mathrm{ha}^{-1}$ and $1,362.04 \mathrm{~kg} \mathrm{ha}^{-1}$, respectively, in agreement with Cruz et al. (2004) results stating that cultivars with regular behaviour in a range of environments are unproductive. Likewise, genotypes LC-029-016, LC-009-016, LC-021-016, L-019, LC-006016 and cultivar Caupicor 50, showed slopes equal to one (1), indicating that they respond favourably to better environmental offers and the deviations of the regression, $\mathrm{S}^{2} \mathrm{di}>0$, highlighting that these are unpredictable (Table 2).

\section{Lin and Binns (1988)}

This method has been applied to different species, including cowpea (Silva et al., 2016); common bean (Melo et al., 2018) and rice (Inácio et al., 2018). According to the superiority index of a cultivar (Pi) established by Lin and Binns (1988), line L-019 was identified as the one with the lowest record (Table 2) and the highest grain yield. This indicates general adaptation to the environments assessed, with less risk of losses due to planting. Then, this line was followed by the commercial cultivar Caupicor 50. In contrast, line LC-021-016 stands out registering a high Pi for all environments. Applying this methodology, Shiringani and Shimelis (2011), Nunes et al. (2014), Silva et al. (2016) and Melo et al. (2018), found similar results related to the parameter $\mathrm{Pi}$, which confirms that those with higher yields are also those with higher adaptability and stability. 


\section{Carneiro (1998)}

Nunes et al. (2014), Sousa et al. (2017) and Melo et al. (2018) have applied this method in cowpea. This methodology breaks down the stability index to identify superior genotypes in favourable (Pif) and unfavourable (Pid) environments, using the same methodology of environmental classification by Eberhart and Russell (1966). According to the records registered in Table 2, these are consistent with results obtained by Lin and Binns (1988), since genotypes with better yields in both favourable and favourable environments and Pif and Pid indices correspond to cultivars L-019 and Caupicor 50. These results are consistent with those reported by Nascimento-Filho et al. (2009), Shiringani and Shimelis (2011), Nunes et al. (2014), Silva et al. (2016), Sousa et al. (2017) and Melo et al. (2018). In this sense, Nascimento et al. (2009) stated that this method as well as the one proposed by Annichiarico (1992), are appropriate to run individually, due to their ease of use, application, and interpretation of genotypes adapted to favourable and unfavourable environments.

\section{Annichiarico (1992)}

This method measures the stability of a genotype through a general confidence index (lig), for favourable environments (lif) and unfavourable environments (lid), in which the highest values of these confidence indices are obtained by those genotypes that exceed the average of the respective environments in percentage terms. This method has been applied by Ramos et al. (2011) in rice and by Pereira et al. (2009) in common bean, aiming at selecting cultivars of high yield and stability.

The results reported in Table 2, highlighting that lines L-019, Caupicor 50 and LC-014-016, exceeded the general average of the environments by $39.04,21.76$ and $1.90 \%$, respectively, with $95 \%$ confidence. In favourable environments, only cultivars L-019 and Caupicor 50, showed a higher value than the average of 46.06 and $23.48 \%$, respectively. On the other hand, for unfavourable environments, in descending order, cultivars L-019, Caupicor 50, LC-014-016 and LC-005-016, showed a higher value of $28.30,18.91,11.97$ and $6.88 \%$, respectively. Therefore, these genotypes are the least risky for planting in typical environments of the Colombian Caribbean region. The coherence and similarity of the methods of Lin and Binns (1988) and Carneiro (1998) with the results obtained with this method is worth noting, corroborating with Ramos et al. (2011), who noted their validity in the identification of genotypes sensitive to the environment.

\section{Nascimento et al. (2009): modified centroids}

This method has been applied in alfalfa (Nascimento et al., 2009), tomato (Pereira et al., 2012) and coffee (Melo-Moura et al., 2017).

Of the seven possible centroids, only four showed presence with a heterogeneous distribution of the genotypes (Table 2, Fig 1). The points closest to the centroids allow, according to Nascimento et al. (2009), giving a recommendation of the genotypes regarding their general or specific adaptabilities to favourable or unfavourable environments.

Line L-019 presented the highest probability of belonging to Class I, with a value of 0.3864 , which can be translated into high adaptability under favourable and unfavourable conditions. This constitutes a good cultivar for the Caribbean region, as a planting alternative for family agriculture of cowpea producers.

Class IV grouped lines LC-029-016 and LC-021-016, with values of 0.2635 and 0.2974 , respectively. These cultivars are characterized as poorly adapted, with a minimum record under favourable conditions and a minimum under unfavourable conditions, since their yields turned out to be lower than the general average.

Class V consists of six genotypes, LC-002-016, LC-036-016, LC009-016, LC-006-016, LC-005-016 and LC-014-016, with values of $0.3862,0.3309,0.2654,0.2557,0.3771$ and 0.2774 , respectively. These genotypes are characterized by having a high general adaptability and an average yield under favourable and unfavourable conditions.

Class VI comprises the commercial cultivar Caupicor 50 with a value of 0.1762 , characterized by a specific adaptability to favourable environments, maximum yield records in favourable environments, and medium in unfavourable environments.

According to Rocha et al. (2005), small difference between any genotype and ideotype I, causes small difference between this genotype and the maximum performance of genotype in all environments. Hence, general adaptability is associated with better performance and higher stability. In this sense, line L019, turned out to be the best with potential for future planting in family agriculture of the Caribbean region.

Based on the results obtained with the five selection methods considering grain yield, we observed that the Eberhart and Russell (1966), that considers adaptability and phenotypic stability as parametric method, was not able to identify the ideal superior genotype that fulfil all of the requirements. However, in the set of genotypes evaluated, line L-019 stands out due to its high yield $\left(1,537 \mathrm{~kg} \mathrm{ha}^{-1}\right)$ and its general adaptability $(\beta=1.0)$, but with low behaviour predictability $\left(S^{2} \mathrm{di}>0\right)$. Nevertheless, the agronomic stability and high phenotypic plasticity enable a cultivar for planting in highcapacity family economy agriculture to dampen climate change effects and respond to technological improvements in production, without sacrificing its yield, since it exceeded the yield of the commercial cultivar Caupicor 50 in approximately $13 \%$. The nonparametric methods are capable of performing simultaneous selection for yield, adaptability and phenotypic stability (Lin and Binns, 1988; Annicchiarico, 1992; Carneiro, 1998; Nascimento et al., 2009). These methods were able to identify line L-019 as the superior genotype compared to control and the rest. However, this is based on a single statistic, enabling them easy to use and interpret by plant breeders (Farshadfar et al., 2012; Abate et al., 2015; Kefelegn et al., 2016). These results demonstrate the genetic potential of L-019 to be considered as a new cultivar for planting in the producing areas of the Colombian Caribbean.

The similarity of the results obtained with the five methods indicates reliability in the selection, according to several 
authors (Nunes et al., 2014; Abate et al., 2015; Kefelegn et al., 2016), who reported the existence of positive and significant correlations between the methods of Eberhart and Russell (1966), Lin and Binns (1988) and Carneiro (1998). According to Lin et al. (1986), although some methods estimate phenotypic stability by different concepts (Type 2, Type 3 - Group C, Type 3 - Group D), the classification or assignment of ranges to genotypes can sometimes be similar, as reported by Sabaghnia et al. (2013).

The advantage of selecting superior genotypes through several analysis methods (parametric and nonparametric) is that it allows obtaining more complementary information and consider different concepts of adaptability and stability when the GxE interaction is significantly present. This makes the selection process of superior genotypes more rigorous, safe, reliable, refined and precise, increasing the chances of success in genetic breeding programs of crops and their adoption by producers (Abate et al., 2015; Kefelegn et al., 2016).

\section{Materials and methods}

\section{Study site}

The study was conducted in eight representative cowpeaproducing areas of the departments of Sampués-Sucre, Montería - Córdoba, Leticia - Bolívar, Polonuevo - Atlántico and Villanueva - Guajira, in conditions of tropical dry forest of the Colombian Caribbean region (Table 3) during the second semester of 2017 and the first semester of 2018. As the number of experiments was not equal in all locations, an "environment" is considered as the combination of a locality each year.

\section{Plant materials}

Ten genotypes were evaluated, representing nine advanced lines obtained by the genetic breeding program of Universidad de Córdoba, as follows: LC-029-016, LC-002-016, LC-036-016, LC-009-016, LC-021-016, L-019, LC-006-016, LC-005-016, LC014-016 and the commercial cultivar Caupicor 50 as a control (Table 4). All these genotypes show characteristics as creamcolored seeds and black hilium that are preferred by producers and consumers.

\section{Experimental design and statistical analysis}

A completely randomized blocks design was used with 10 treatments and four repetitions per environment. The experimental units were $3.2 \mathrm{~m}$ wide by $5 \mathrm{~m}$ long, for an area of $16 \mathrm{~m}^{2}$. Grain yield data were subjected to their respective analysis of individual variance for each environment, to the Shapiro and Wilk normality tests and variance homogeneity of Bartlett (Steel and Torrie, 1980), followed by a combined analysis of variance and mean tests. The genotypes were considered as fixed effects and the environments as random.

\section{Adaptability and stability methods}

Once the significance of the GXE interaction was detected, adaptability and phenotypic stability were estimated through the following methods: Eberhart and Russell (1966), Lin and Binns (1988), Annichiarico (1992), Carneiro (1998), and Nascimento et al. (2009). Table 5 shows the formulas for estimating the different indices of each method.

\section{Applied software}

Windows GENES V.2014.6.1 (Cruz, 2016) was used for the analysis of combined variance of grain yield and likewise, to estimate the adaptability and stability indexes of each applied method

\section{Conclusion}

The five adaptability and stability methods used were similar, coherent and easy to interpret in the identification of desirable or superior cultivars in favourable and unfavourable environments. Genotype L-019 showed the best average yield and phenotypic stability in the eight environments evaluated. So, it can be recommended for commercial release and planting in the cowpea-producing areas in the departments assessed of the Colombian Caribbean region.

\section{Acknowledgements}

The Authors express their gratitude to Universidad de Córdoba, Colciencias and Fundación Promotora Canal del Dique for their support and for financing this research, likewise, to all small producers that allowed us to carry out the experiments in their plots.

\section{References}

Abate F, Mekbib F, Dessalegn Y (2015) Association of different parametric and non-parametric stability models in durum wheat (Triticum turgidum Desf.) genotypes. Int J Plant Soil Sci. 7(4): 192-201.

Annicchiarico P (1992) Cultivar adaptation and recommendation from alfalfa trials in Northern Italy. J Genet Breed. 46(3): 269-278.

Carneiro P (1998) Novas metodologías de análisis da adaptabilidade e estabilidade de comportamiento. Tese Doutorado. Universidade Federal de Viçosa, Viçosa-MG Brasil. 168p.

Cholin S, Uma MS, Biradar S, Salimath PM (2010) Stability analysis for yield and yield components over seasons in cowpea [Vigna unguiculata L. (Walp.)]. E J PI Breed. 1(6):1392-1395.

Cruz CD, Regazzi AD, Carneiro PCS (2004) Modelos biométricos aplicados ao melhoramento genético. 3ed. Universidade Federal de Viçosa, Viçosa, Brasil 480 pp

Cruz CD (2016) Programa Genes V.2014.6.1 - Aplicativo computacional em genética e estatística. Disponible desde internet en http://www,ufv,br/dbg/genes/genes.htm [con acceso el 22/09/2016]. 
Eberhart SA, Russell WA (1966) Stability parameters for comparing varieties. Crop Sci. 6 (1): 36-40.

FAOSTAT. 2018. Data. Crops. http://www.fao.org/faostat/ en/\#data/QC. Accessed on august 25, 2018.

Farshadfar E, Sabaghpour S, Zali H (2012) Comparison of parametric and non-parametric stability statistics for selecting stable chickpea (Cicer arietinum L.) genotypes under diverse environments. Aust J Crop Sci. 6(3): 514-524.

Gedif M, Yigzaw D, Tsige G (2014) Genotype-environment interaction and correlation of some stability parameters of total starch yield in potato in Amhara region, Ethiopia. J Plant Breed Crop Sci. 6(2): 31-40.

Hühn M (1990) Non-parametric measures of phenotypic stability: Part 1. Theory. Euphytica. 47(3): 189-194.

Inácio HB, Botelho F, Moura AM, Mendes-Resende M, Santos HO, Castro AP, Reis M, Bustamante FO (2018) Phenotypic plasticity of upland rice lines cultivated in Minas Gerais State, Brazil. Aust J Crop Sci. 12(05): 763-769.

Karimizadeh R, Mohammadi M, Sabaghnia N, Shefazadeh M, Pouralhossini J (2012) Univariate stability analysis methods for determining genotype $x$ environment interaction of durum wheat grain yield. Afr J Biotech. 11(1): 2563-2573.

Kefelegn N, Mekbib F, Desalegn Y (2016) Association of stability models in measuring stability of common bean varieties. Am J Exp Agric. 10(5): 1-9.

Lin C, Binns M, Lefkovitch L (1986) Stability analysis: where do we stand? Crop Sci. 26(1): 894-900.

Lin CS, Binns MR (1988). A superiority measure of cultivar performance for cultivar $\mathrm{x}$ location data. Can J Crop Sci. 68(1): 193-198.

Liu Y, Hu W, Yuan-qi W, Yu-bi H (2011) Yield stability of maize hybrids evaluated in national maize cultivar regional trials in Southwestern China using parametric methods. Agric Sci China. 10(9): 1323-1335.

Malosetti M, Ribaut JM, Eeuwijk FA (2013) The statistical analysis of multi-environment data: modeling genotype-byenvironment interaction and its genetic basis. Front Physiol. 4: 44.

Melo PGS, Alvares RC, Pereira HS, Braga AJ, Faria LC, Cunha L (2018) Adaptability and stability of common bean genotypes in family farming systems. Pesq Agropec Bras. 53 (2):189196.

Melo-Moura W, Oliveira AM, Gonçalves DR, Carvalho CF, Oliveira RL, Cruz CD (2017) Adaptability and stability of organic-grown arabica coffee production using the modified centroid method. Crop Breed Appl Biotechnol. 17(4): 359365.

Nascimento M, Cruz CD, Campana ACM, Tomaz RS, Salgado CC, Ferreira RP (2009). Alteração no método centróide de avaliação da adaptabilidade genotípica. Pesq Agropec Bras. 44(3):263-269.
Nunes H, Freire Filho F, Ribeiro V, Gomes R (2014) Grain yield adaptability and stability of blackeyed cowpea genotypes under rainfed agriculture in Brazil. Afr J Agric Res. 9(2): 255261.

Pereira HS, Melo LC, Faria LC de, Del Peloso MJ, Costa, JGC da, Rava CA, Wendland A (2009) Adaptabilidade e estabilidade de genótipos de feijoeiro-comum com grãos tipo carioca na Região Central do Brasil. Pesq Agropec Bras. 44(1): 29-37.

Pereira MA, Azevedo SM, Freitas GA, Santos GR, Nascimento IR (2012) Adaptabilidade e estabilidade produtiva de genótipos de tomateiro em condições de temperatura elevada. Rev Ciênc Agron. 43(2): 330-337.

Ramos LM, Sanches A, Cotes JM, Cargnelutti Filho A (2011). Adaptabilidade e estabilidade do rendimento de genótipos de arroz, mediante duas metodologías de avalicao na Colombia. Acta Agron. 60(1): 39-49.

Rocha RB, Muro-Abad JI, Araujo EF, Cruz CD (2005). Avaliação do método centroide para estudo de adaptabilidade ao ambiente de clones de Eucalyptus grandis. Ci Fl. 15(3): 255266.

Sabaghnia N, Mohammadi M, Karimizadeh R (2013) Yield stability of performance in multi environment trials of barley (Hordeum vulgar L.) genotypes. Acta Univ Agric Silvic Mendelianae Brun. 61(3): 787-793.

Sahin E, Zeinalzadeh T, Tosun M (2012) Genotype by environment interaction and stability analysis of orchardgrass (Dactylis glomerata L.) ecotypes for seed yield in Erzurum, Turkey. Intl J Agric and Crop Sci. 4(2): 45-50.

Shiringani RP, Shimelis HA (2011) Yield response and stability amog cowpea genotypes at three planting dates and test environment. Afr J Agric Res. 6 (14):3259-3263.

Silva Do, Santos CA, Boiteux L (2016) Adaptability and stability parameters of total yield and protein content in cowpea (Vigna unguiculata) genotypes subjected to semi-arid conditions. Aust J Crop Sci. 10(8): 1164-1169.

Sousa MB, Kaesel JD, Rocha MM, Menezes-Junior JA, Lima RL (2017) Adaptability and yield stability of cowpea elite lines of semi-prostrate growth habit in the cerrado biome. Rev Ciênc Agron. 48(5): 832-839.

Steel RGD, Torrie JH (1980) Principles and procedures of statistics, second ed. A Biometrical Approach McGraw-Hill Book Co, New York. 633p.

Vange T, Ango I, Adedzwa D (2014) Stability analysis of six improved Sorghum genotypes across four environments in the Southern Guinea Savanna agroecological zone of Nigeria. Int J Adv Agric Sci Tech. 2(2): 01-14.

Vilela FO, Amaral - Júnior AT, Gonçalves LSA, Barbé TC, Gravina GA (2011). Stability of F7:8 snap bean progenies in the Northern and Northwestern regions of Rio de Janeiro State. Hortic Bras. 29(1): 84-90. 